\title{
CHARACTERIZATION OF ABU KHRUQ NEPHELINE SYENITE AND ITS COMPENSATION WITH SODA-LIME-GLASS FOR PREPARATION OF GLASS- CERAMIC
}

\author{
Hamzawy, E. M. $A^{2}$, Soltan, $A^{1}$, El Kalioubi, B ${ }^{1}$ and Yahya, A. M. ${ }^{1}$. \\ ${ }^{1}$ Geology Department, Faculty of Science, Ain Shams University, Cairo, Egypt. \\ ${ }^{2}$ Glass Research Department, National Research Centre, Dokki, P.C. 12622, Cairo, Egypt.
}

\begin{abstract}
The Abu Khruq ring complex (ARC) is located in the Southern Eastern Desert of Egypt. It is composed mainly of nepheline syenite, syenite and quartz syenite. Petrographical and chemical analysis (XRF) were achieved to identify the mineral composition and to define the nature of the various rock types present in the area.

Geochemically, the different types of alkaline syenitic rocks from margin and the center of the ring show decrease of $\mathrm{Na}_{2} \mathrm{O}$ and enrichment of $\mathrm{SiO}_{2}$ toward the margin. The syenitic rocks have a considerable value of $\mathrm{Al}_{2} \mathrm{O}_{3}(12.8$ - 17.3 wt. \%) and total alkalis are above 8.5 wt.\% which might indicate magma developed from deep crustal source of mixed material from the mantle. According to plate tectonic theory, the different types of syenitic rocks placed in within plate anorogenic belts.

Sintered glass-ceramic was prepared from local nepheline syenite with soda-lime-silicate glass. $\mathrm{B}_{2} \mathrm{O}_{3}$ added to the glass batches to decrease the melting temperature as well as the glass melt viscosity. $\mathrm{MgF}_{2}$ and $\mathrm{CaF}_{2}$ were added to the glass batches as nucleation catalysts. Little nepheline, augite, xonotlite and fluorite were developed in the samples after sintering process. Very little or traces of nepheline was formed in boron-free and -containing sample. Although $\mathrm{MgF}_{2}$ enhance augitic pyroxene, $\mathrm{CaF}_{2}$ appropriate the formation of xonotlite. In all samples nano- and micro-size rods were developed in the glassy matrix. The Vickers microhardness and densities values were between $\sim 396.5$ to $676.2 \mathrm{~kg} / \mathrm{mm}^{2}$ and $\sim 2.14$ to 2.52 $\mathrm{g} / \mathrm{cm}^{3}$, respectively. The produced glass-ceramic can be used in building materials.
\end{abstract}

Keywords: Raw material, glass ceramics, xonotlite and augite.

\section{INTRODUCTION}

Ring complexes in Egypt generally evolved during Phanerozoic age (550- $80 \mathrm{Ma})$, which can be classified to four groups, the first one emplaced during Paleocene $(550-313 \mathrm{Ma})$, the second evolved during Permo-Triassic age $(230-200 \mathrm{Ma})$, the third one occurred at late Jurassic-Early Cretaceous age $(160-120 \mathrm{Ma})$, and the last one of Late Cretaceous ago (110-80 Ma) (Serecsists et al. 1979; Hashad and El Reedy 1979; Meneisy and Kreuzer 1974). El Ramly and Hussein (1985) classified the ring complexes, on the basis of variety of rocks, their magmatic differentiation and on the degree of development of the ring nature and complexity of the structure, into five type groups: 1- Abu Khruq ring complex, 2- Gezira ring complex, 3- Mishbeh ring complex, 4- Mansouri ring complex, 5- Tarbtie ring complex.

Abu Khruq ring complex includes volcanic rocks and sub-volcanic intrusions forming number of incomplete ring dykes of various alkaline syenites in addition to cones, sheets and stock-like bodies of nepheline syenites. These types are found in Gebel Abu Khruq, El Naga, El Kahfa and Nigrub.

Abu Khruq ring complex represented the main type of alkaline rocks in Egypt, which belongs to the latest group in Late Cretaceous ( $89 \pm 2 \mathrm{Ma}$ ago) (Lutz et al. 1988). This ring complex consists of a wide variety of rocks including syenitic rocks and their volcanic equivalent. Their rocks range between undersaturated to over- saturated with clear alkaline affinities (El Ramly and Hussein 1982 and 1985; El Afandy et al. 2012 and Mogahed, 2016). 


\section{Hamzawy, et al.}

These rocks are considered as natural raw materials to be exploited in glass ceramic production. In contemporary years, syenites and nepheline syenite have been used gainful in manufacture of glass ceramics because of achieving mechanical and chemical properties.

Glass ceramic is a polycrystalline material produced throughout the heat-treatment of pre- prepared glass. There are many types of parameters which control development of crystalline phases and fabric of microstructures. These parameters are chemical composition, nucleating agents, heat-treatment, developed phases, etc. The controlled crystallization may be depended on efficient nucleation (Aitken and Beall, 1994). The properties of glass ceramics are defined by the inherent features and the microstructures resulting from the nucleation and growth processes (Beall, 1989). The purpose of influential nucleating agent has permitted the development of greatly crystalline material of widespread industrial application (McMillan, 1979). Pyroxenes and feldspathoids are most desirable mineral phases, developed in $\mathrm{Na}_{2} \mathrm{O}-$ $\mathrm{K}_{2} \mathrm{O}-\mathrm{CaO}-\mathrm{Fe}_{2} \mathrm{O}_{3}-\mathrm{Al}_{2} \mathrm{O}_{3}-\mathrm{SiO}_{2}$ glasses due to their interesting properties (Hamzawy and Khater, 2005). The fluorspar or $\mathrm{CaF}_{2}$ can facilitate the development of aluminum silicate glass ceramics with fine grained microstructure (Salama, et al., 2002). Also, fluorspar improves initial crystallization of aluminum silicate glass system by lowering both of crystallization peak temperature and activation energy (Mukherjee, and Das, 2012). On the other hand, $\mathrm{MgF}_{2}$ promote initial crystallization of $\mathrm{Li}-\mathrm{Al}_{2} \mathrm{O}_{3}-\mathrm{SiO}_{2}$ system and diffusion in this glass (An-Min, et al., 2004).

\section{GEOLOGICAL SETTING}

Abu Khruq Complex is located between latitudes $24^{\circ} 38^{\prime} 10^{\prime \prime}$ and $24^{\circ} 41^{\prime} 15^{\prime \prime} \mathrm{N}$ in the Southern Eastern Desert, about $60 \mathrm{Km}$ far from Wadi El-Gemal protected area. This area looks like dissected elliptical two rings with diameter $4 \mathrm{Km}$. Gabal Abu Khruq represent alkaline rock type in two form, extrusive and intrusive rocks which had been formed from about 89 million years ago (Fig. 1). These two types consist of alkaline trachyte and rhyolitic porphyry as extrusive type at the center of the ring followed by alkaline gabbroic and syenitic rocks comprises oversaturated to under-saturated syenites. The form of these rocks is diverse in shape as dissected ring, cone, sheets and stock like bodies (El Ramly, et al., 1969 and El Afandy, et al., 2012). The lithologies created at the same time and place as another consequently they are represented as indistinguishable ages in this area (El Afandy and Abdalla, 2001).

\section{PETROGRAPHY}

The studied syenitic rocks of Abu Khruq ring complex is intervened into Late Proterozoic Pan African country rocks. Generally, Mineral proportions permit the rocks to be classified into under-saturated composition, transitional to be over-saturated for the alkaline rocks of Abu Khruq ring complex area.

Syenites are medium to coarse grained massive bodies that were affected by alteration processes on the surface. They are distinguished in the field by its grayish to pinkish white color. Microscopically, they mainly consist of perthitic orthoclase, albite, ageirine and ageirine-augite with minutes of opaque minerals as iron oxide as well as zircon and apatite. They have some of quartz less than 5\%. Alkali feldspar occurred as euhedral to subhedral lathes perthite with diverse size, albitic plagioclase detected as small prismatic subhedral grained and mafic minerals are including aegirine and aegirine-augite which are found as aggregated associated with minutes of iron oxides and closed to perthitic lathes.

Quartz Syenites are generally similar to syenites as massive and sometimes showed altered surfaces except they have a higher proportion of modal quartz by $10 \%$. They are clearly showed affected by shear forces. Petrographically, they are composed of elongated subhedral to anhedral crystals of alkali feldspar perthite, albitic plagioclase, quartz, aegirine-augite and alkali amphibole. In addition to, minor mounts of zircon and opaque minerals. Quartz occurred as anhedral grained and sometimes associated with alkali feldspar to form graphic texture. Aegirine-augite and alkali amphibole are detected subhedral crystals associated iron oxides and heavy minerals as zircon, which enclosed by perthite lathes.

Nepheline Syenites occurred as hard, massive and ellipsoidal in the field with grayish white in color. Petrographically, they consist of medium to coarse grained, composed of lathes of alkali feldspar perthite, 


\section{Characterization of Abu Khruq nepheline syenite}

albite, nepheline, aegirine-augite and biotite with minutes of analcite, concrinite and accessory minerals. Generally, they show an equigranular hypidiomorphic texture. Nepheline crystals usually occurred interfered with perthitic lathes, and sometimes altered to muscovite pseudomorphous. Aegirine-augite occurred as subhedral crystals. Perthitic orthoclase occurred in small prismatic subhedral grained usually show Carlsbad twins.

Fig. 1: Ring complexes in the Eastern Desert of Egypt (After El Ramly and Hussein, 1985).

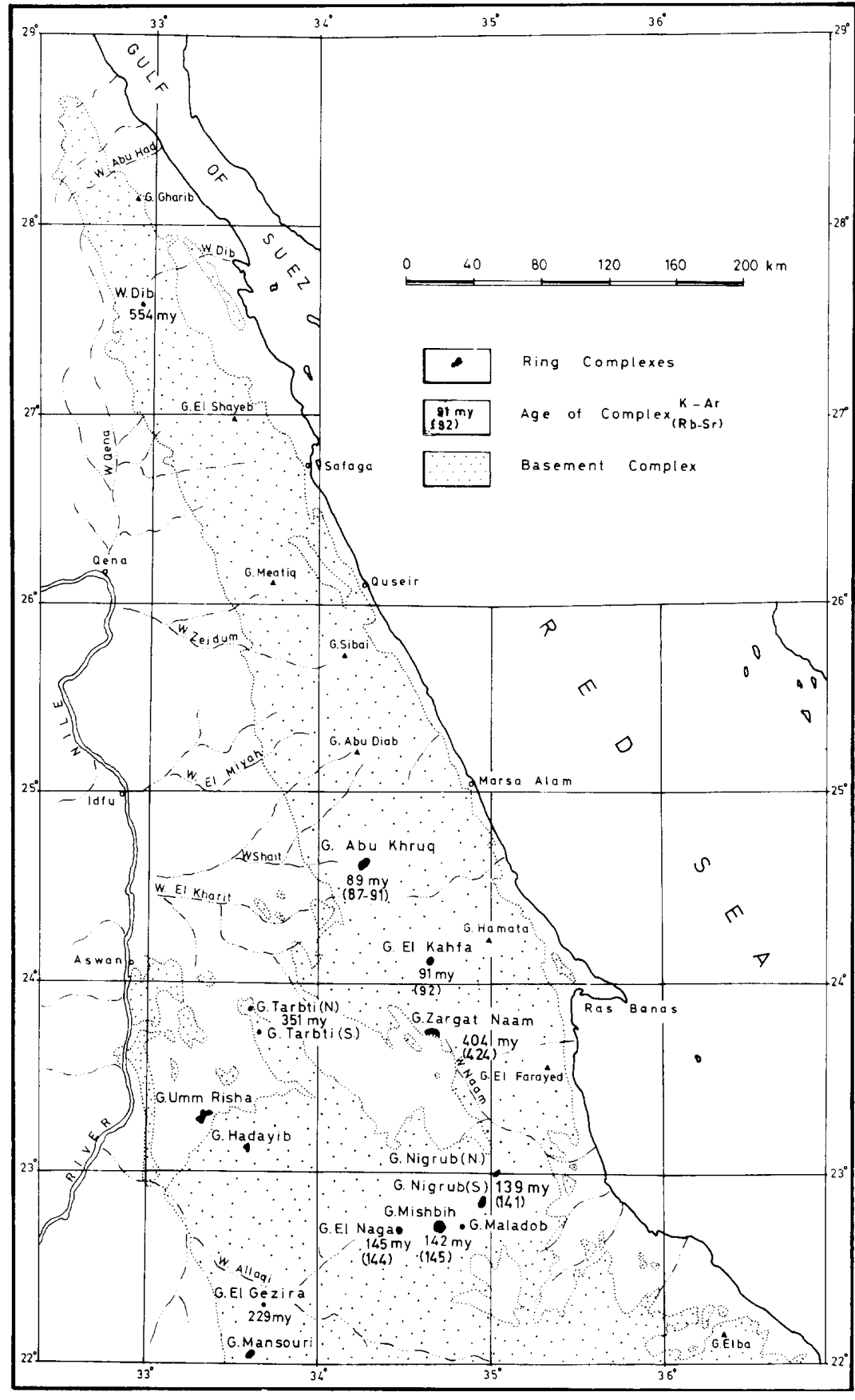

GEOCHEMISTRY

Seven samples were selected from different types of syenites of Abu Khruq Complex for chemical analysis of major oxides and trace elements using XRF technique in the Central laboratories of the Geological Survey of Egypt. The results with CIPW normative are listed in Table 1. 
Hamzawy, et al.

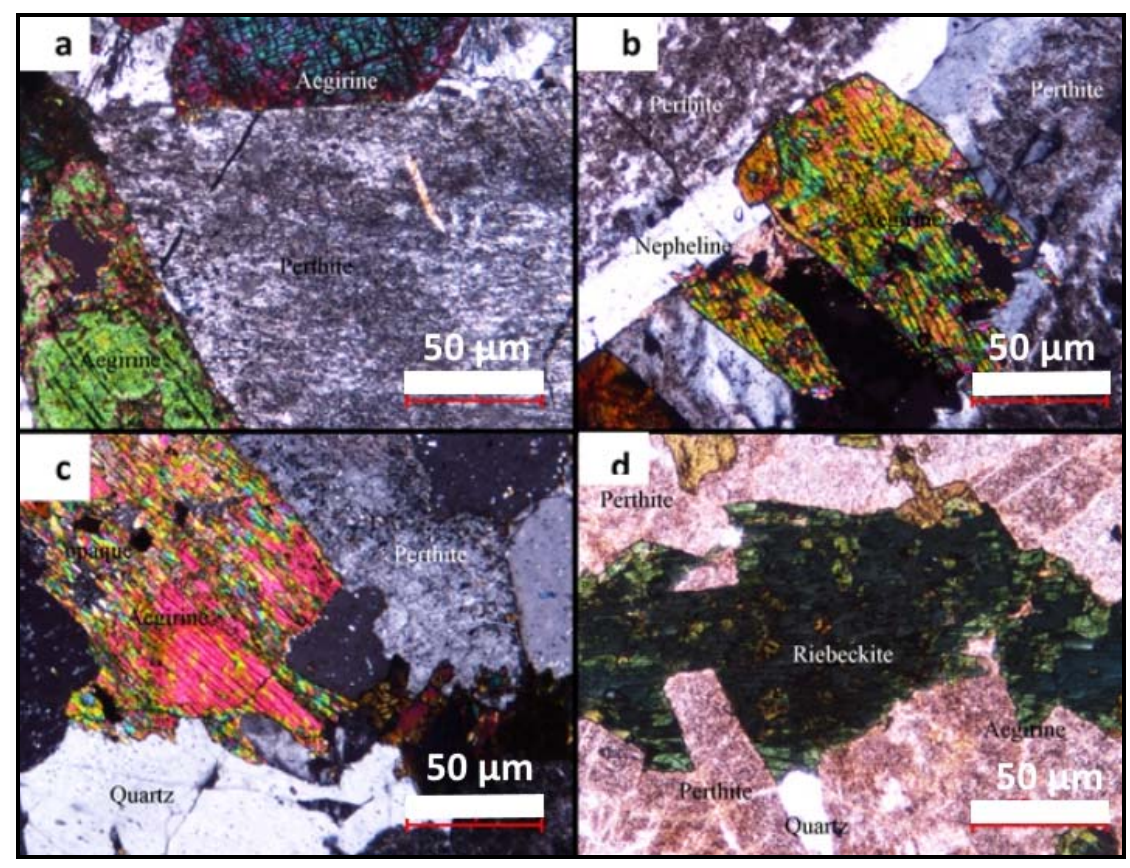

Fig. 2: Photomicrographs of Abu Khruq syenites: a- Phenocrysts of aegirine in Syenite with inclusions of opaque, and laths of perthitic orthoclase, C.N. b- Phenocrysts of aegirine, nepheline and orthoclase perthitic laths, in nepheline syenite C. N. c- Quartz Syenite with quartz phenocrysts, aegirine and perthitic alkali feldspar, C.N. D- Phenocryst of riebeckite, aegirine as well as perthitic alkali feldsparin syenite, PPL.

Table 1: Major and trace elements of alkaline samples.

\begin{tabular}{|c|c|c|c|c|c|c|c|}
\hline Sample & $\begin{array}{l}\text { Nepheline } \\
\text { syenite }\end{array}$ & Syenite & $\begin{array}{l}\text { Quartz Syenite } \\
\text { porphyry }\end{array}$ & \multicolumn{4}{|c|}{ Quartz syenite } \\
\hline \multicolumn{8}{|c|}{ Major oxides } \\
\hline $\mathrm{SiO}_{2}$ & 59.62 & 62.52 & 61.95 & 66.42 & 67.49 & 67.52 & 68.03 \\
\hline $\mathrm{TiO}_{2}$ & 0.27 & 0.81 & 0.38 & 0.34 & 0.34 & 0.71 & 0.4 \\
\hline $\mathrm{Al}_{2} \mathrm{O}_{3}$ & 17.3 & 15.52 & 15.52 & 14.7 & 14.25 & 12.83 & 13.3 \\
\hline $\mathrm{Fe}_{2} \mathrm{O}_{3}$ & 6.67 & 7.91 & 7.48 & 5.59 & 6.04 & 8.11 & 6.15 \\
\hline MnO & 0.24 & 0.29 & 0.21 & 0.17 & 0.13 & 0.12 & 0.22 \\
\hline MgO & $<0.01$ & $<0.01$ & $<0.01$ & 0.32 & $<0.01$ & $<0.01$ & $<0.01$ \\
\hline $\mathrm{CaO}$ & 1.1 & 0.64 & 1.05 & 0.48 & 0.59 & 0.3 & 0.97 \\
\hline $\mathrm{Na}_{2} \mathrm{O}$ & 5.9 & 6.32 & 5.87 & 5.36 & 6.63 & 4.79 & 4.14 \\
\hline $\mathrm{K}_{2} \mathrm{O}$ & 6.5 & 4.50 & 5.29 & 5.61 & 3.57 & 5.03 & 4.85 \\
\hline $\mathbf{P}_{2} \mathbf{O}_{5}$ & 0.04 & 0.04 & 0.19 & $<0.01$ & $<0.01$ & 0.02 & $<0.01$ \\
\hline LOI & 2.07 & 1.32 & 1.57 & 0.5 & 0.63 & 0.2 & 1.35 \\
\hline Total & 59.62 & 62.52 & 61.95 & 66.42 & 67.49 & 67.52 & 68.03 \\
\hline \multicolumn{8}{|c|}{ Trace elements } \\
\hline $\mathbf{V}$ & 17.4 & 40.6 & 21.7 & 24.5 & 26.7 & 31.5 & 24.6 \\
\hline $\mathbf{C r}$ & 36.3 & 35.3 & 46.9 & 55.4 & 36.2 & 47.2 & 45.5 \\
\hline $\mathbf{N i}$ & 14.8 & 17.4 & 19.5 & 22.8 & 17.1 & 18.9 & 20.7 \\
\hline $\mathrm{Cu}$ & 3.9 & 2.4 & 4.9 & 3.6 & 4.3 & $<2.0$ & $<2.0$ \\
\hline Zn & 186.7 & 233.8 & 174.0 & 158.9 & 149.0 & 147.9 & 263.8 \\
\hline Co & 17.2 & 24.7 & 15.4 & 13.0 & 14.6 & 22.2 & 17.4 \\
\hline Ga & 34.5 & 38.0 & 34.8 & 36.6 & 37.2 & 38.4 & 39.6 \\
\hline $\mathbf{R b}$ & 140.6 & 82.9 & 108.2 & 120.1 & 79.8 & 95.1 & 133.3 \\
\hline Sr & 36.9 & 50.9 & 79.9 & 17.6 & 120.4 & 29.2 & 40.5 \\
\hline $\mathbf{Y}$ & 96.7 & 72.9 & 78.8 & 107.5 & 46.6 & 60.0 & 159.0 \\
\hline $\mathbf{Z r}$ & 1392.5 & 645.1 & 979.1 & 1297.4 & 616.9 & 563.0 & 1397.4 \\
\hline Nb & 148.5 & 97.4 & 112.8 & 86.7 & 63.5 & 63.8 & 148.8 \\
\hline Ba & 13.8 & 339.8 & 358.2 & 148.1 & 1060.6 & 337.3 & 388.6 \\
\hline La & 190.9 & 108.2 & 139.9 & 112.5 & 88.2 & 90.9 & 148.1 \\
\hline Yb & 4.7 & 4.3 & 9.6 & 11.3 & $<2.0$ & 5.7 & 15.2 \\
\hline Ta & 2.5 & 2.5 & 2.3 & 2.2 & 2.1 & 2.2 & 2.5 \\
\hline $\mathbf{P b}$ & 14.9 & 10.3 & 14.4 & 17.8 & 11.2 & 9.6 & 11.8 \\
\hline Th & 34.2 & 17.1 & 23.9 & 26.6 & 12.5 & 5.8 & 32.8 \\
\hline
\end{tabular}




\section{Characterization of Abu Khruq nepheline syenite}

\section{Classification of alkaline rock samples}

De La Roche et al. (1980) proposed a chemical classification of intrusive rocks based on $\mathrm{R}_{1}=4 \mathrm{Si}-11$ $(\mathrm{Na}+\mathrm{K})-2(\mathrm{Fe}+\mathrm{Ti})$ versus $\mathrm{R}_{2}=6 \mathrm{Ca}+2 \mathrm{Mg}+\mathrm{Al}$ binary diagram (Fig. 3a). The figure shows that quartz syenite samples plot within quartz syenite field except one sample was shifted to alkali granite field due to increasing amount of normative quartz, whereas syenite samples plot within syenite field and nepheline syenite fall in nepheline syenite field. According to classification of Le Maitre (1989) based on $\mathrm{SiO}_{2}$ versus $\mathrm{Na}_{2} \mathrm{O}+\mathrm{K}_{2} \mathrm{O}$ wt. \%, all samples are plotted in syenite field except on sample located at nepheline syenite field (Fig. 3b).

\section{Magma Type}

MacDonald (1968) illustrated type of magma is alkaline or sub-alkaline based on $\mathrm{SiO}_{2}$ versus total alkali $\left(\mathrm{Na}_{2} \mathrm{O}+\mathrm{K}_{2} \mathrm{O}\right)$ binary diagram (Fig. $\left.4 \mathrm{a}\right)$. All selected samples plot in alkaline field to distinguish type of origin these rocks came from alkaline origin. On the binary diagram (Fig. 4b) of ANK versus ANCK for Maniar and Piccoli (1989). All samples are located within per-alkaline to very slightly metaluminous field. Wright (1969) determined magma type according to alkalinity ratio versus $\mathrm{SiO}_{2}$. Samples fall within range between strong alkaline to per-alkaline fields (Fig. 4c). On $\mathrm{Al}_{2} \mathrm{O}_{3}-\mathrm{Na}_{2} \mathrm{O}-\mathrm{K}_{2} \mathrm{O}$ ternary diagram proposed type of origin magma. Selected sample is located at the range between strongly alkaline (per-aluminous) to peralkaline (Fig. 4d). All samples of Abu Khruq fall within the peraluminous field in a ternary diagram Shand (1951) (Fig.4e) however absence of normative corundum besides, the presence of acmite is attributed to the secondary alkali enrichments. Therefore, Lameyre (1974) suggested that the increasing of alkali and decreasing of alumina cause the presence of normative acmite.

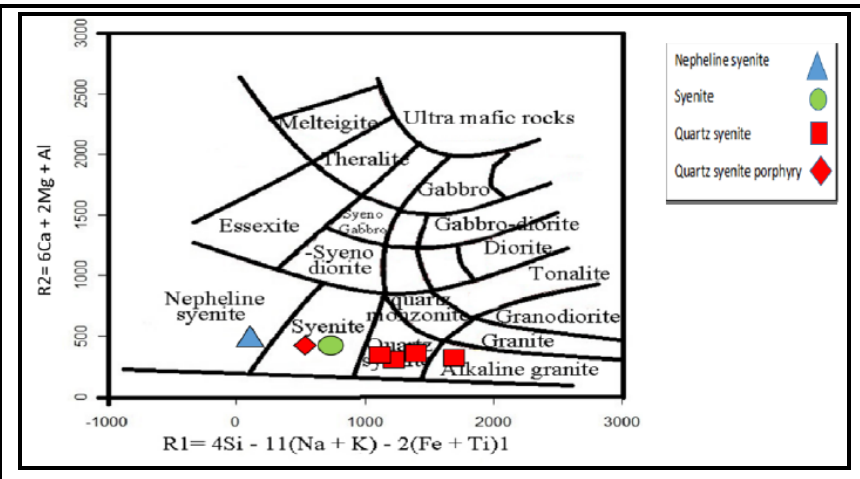

$\mathrm{B}$

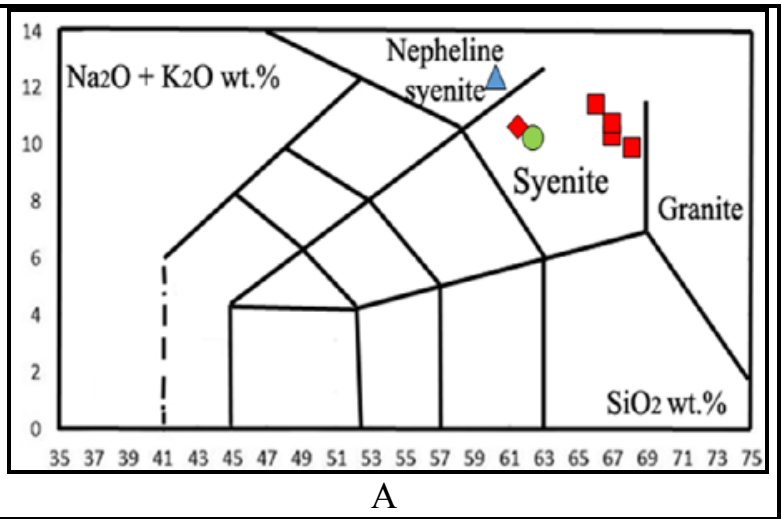

A

Fig. 3: Classification of Abu Khruq syenitic rock samples. A. R1-R2 nomenclature diagram (de la Roche et al. 1980). B- $\mathrm{SiO}_{2}-\mathrm{Na}_{2} \mathrm{O}+\mathrm{K}_{2} \mathrm{O}$ (wt. \%) nomenclature diagram of Le Maitre 1989.

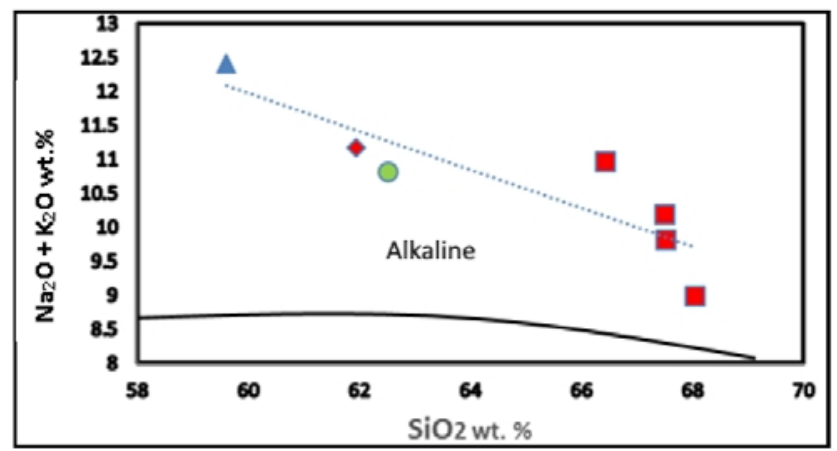

Fig. 4a: Alkali-silica diagram of Irvine and Baragar (1971).

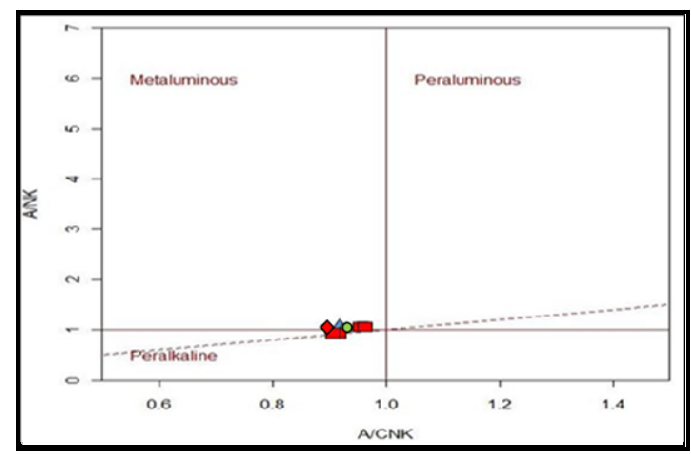

Fig. 4b: A/CNK versus A/NK diagram (After Maniar and Piccoli, 1989). 
Hamzawy, et al.

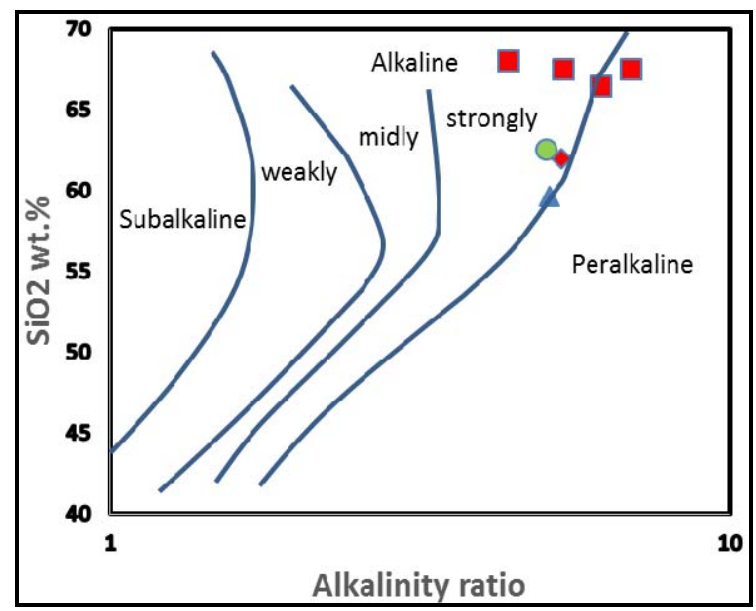

Fig. 4c: Alkalinity ratio diagram of Wright (1969).

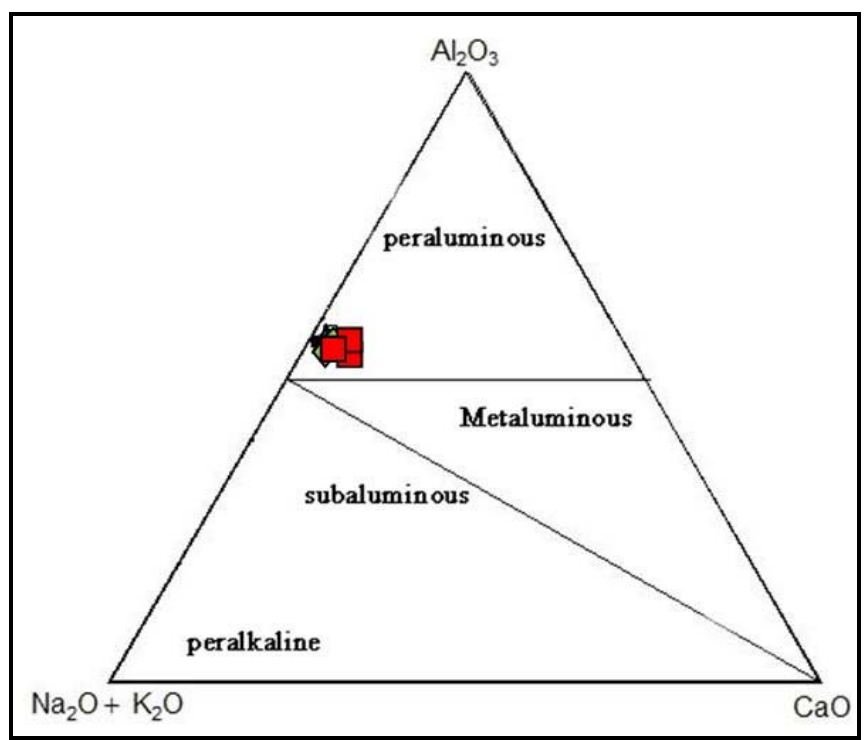

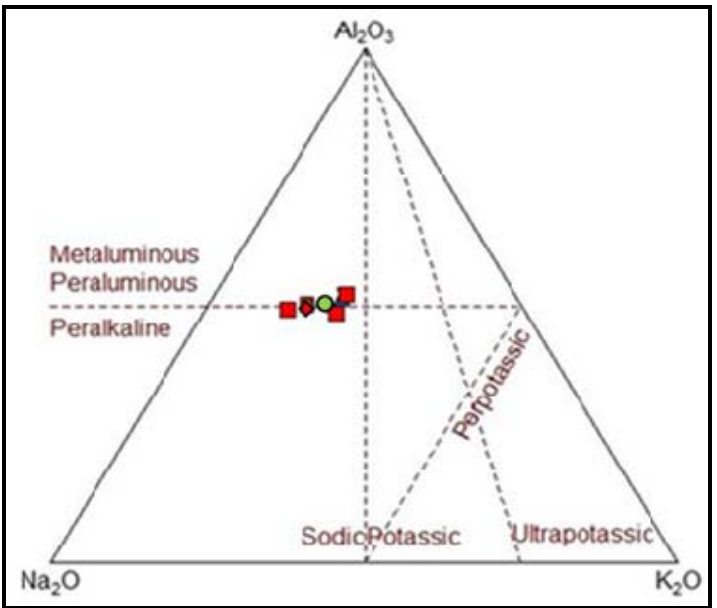

Fig. 4d: Molar $\mathrm{Na}_{2} \mathrm{O}-\mathrm{Al}_{2} \mathrm{O}_{3}-\mathrm{K}_{2} \mathrm{O}$ diagram for the studied alkaline rocks (after Bonin, 1974).

Fig.4e: $\mathrm{Al}_{2} \mathrm{O}_{3}-\mathrm{Na}_{2} \mathrm{O}+\mathrm{K}_{2} \mathrm{O}-\mathrm{CaO}$ ternary diagram of Shand (1951).

On the binary diagram of $\mathrm{Y}-\mathrm{Nb}$ and $(\mathrm{Y}+\mathrm{Nb})-\mathrm{Rb}$ of Pearce et al. (1984), all samples are located at within plate field (Fig. 5a and b), which is in accordance with the anorogenic affinities as revealed by R1-R2 diagram (Batchelor and Bowden 1985) (Fig. 5c).

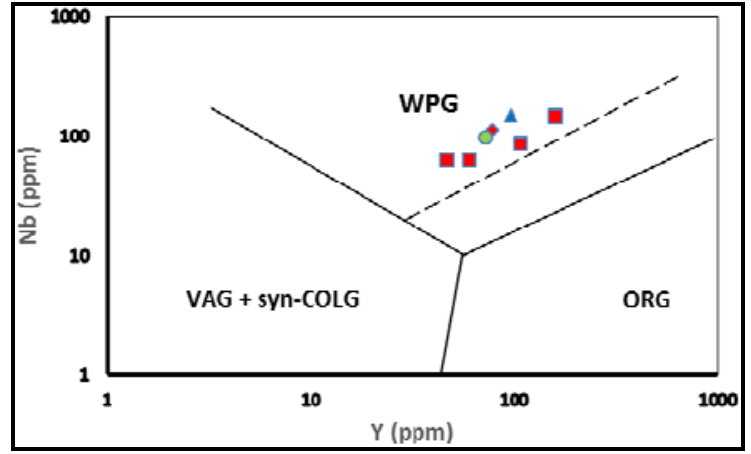

Fig. 5a: $\mathrm{Y}$ versus $\mathrm{Nb}$ diagram of Pearce et al. (1984).

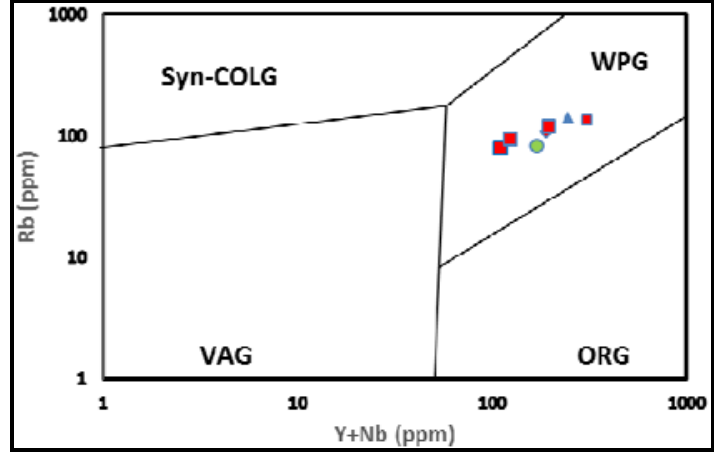

Fig. $5 \mathrm{~b}: \mathrm{Y}+\mathrm{Nb}$ versus $\mathrm{Rb}$ diagram of Pearce et al. (1984). 


\section{Characterization of Abu Khruq nepheline syenite}

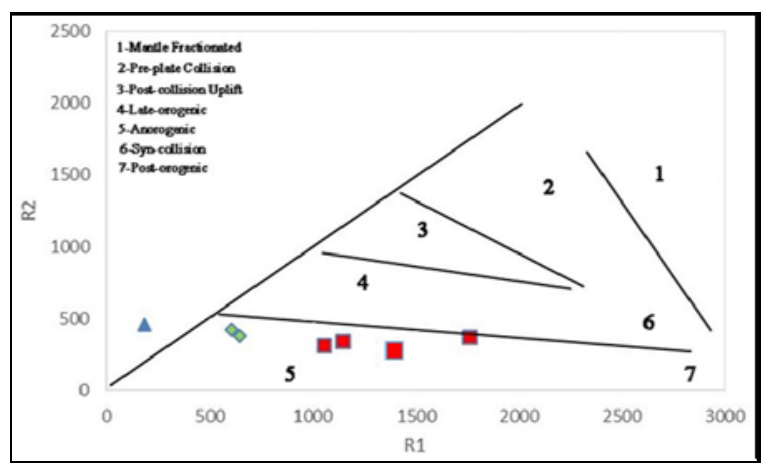

Fig. 4i: R1-R2 diagram of Batchelor and Bowden (1985).

Based on the chondrite-normalized trace elements by Thompson, et al. (1984) diagram, the alkaline rocks of Abu Khruq exhibit enrichment of LIL element $\mathrm{Nb}, \mathrm{Y}$ and $\mathrm{Zr}$ and, depletion in Rb and $\mathrm{Sr}$ (Fig. 6).

Fig.6: Primordial mantelSpider diagram of Thompson, et al. (1984).

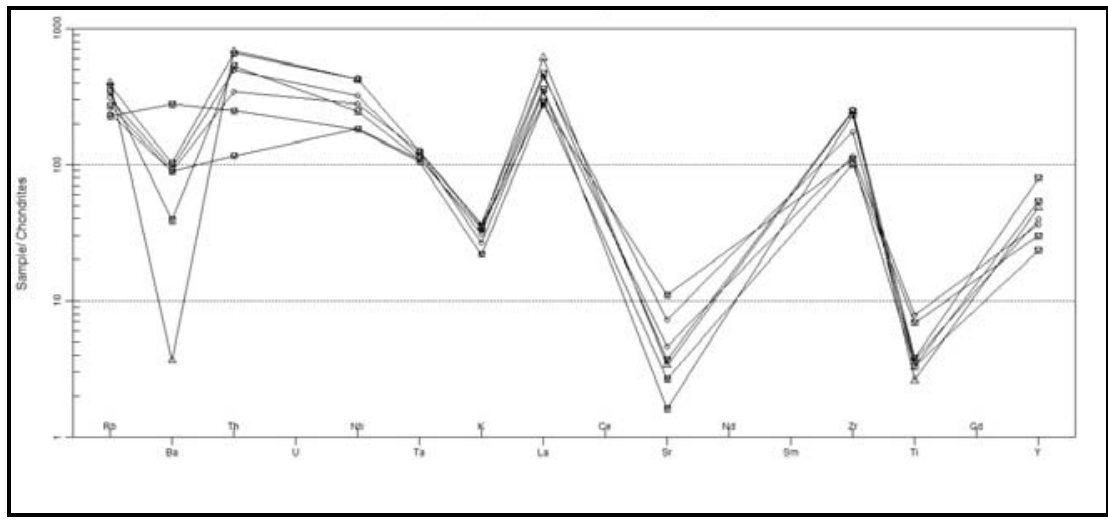

\section{Material and Experimental methods for glass ceramics}

In Abu Khruq area, Syenites raw materials have different grades according to the iron ratio. In the present work the low iron ratio syenites-mix was used. The starting materials of the batches were low iron nepheline syenite and soda-lime-silica glass and the chemical composition of raw material are mentioned in table (2). Boric acid was added as source of $\mathrm{B}_{2} \mathrm{O}_{3}$ as flux to lower the melting temperature. Also, $\mathrm{MgF}_{2}$ and $\mathrm{CaF}_{2}$ were added as nucleating agents in different ratio (Table 3). The weighed batches were mixed in a laboratory size ball mill and put in platinum crucible for melting process in a temperature range 1450-1500 ${ }^{\circ} \mathrm{C}$ for 2 hours. Glass frits were crushed and ground up to $(<0.053 \mathrm{~mm})$, and was uniaxially compressed to pellet in a hydraulic operated pellet press at $20 \mathrm{KN}$. Pellets were divided and putted in muffle furnace for an sintering process at $750,800,850,900$ and $950^{\circ} \mathrm{C}$ for 2 hours separately.

Table 2: Chemical composition of the raw materials (wt. \%)

\begin{tabular}{|l|l|l|l|l|l|l|l|l|c|}
\hline Raw material & $\mathrm{SiO}_{2}$ & $\mathrm{Al}_{2} \mathrm{O}_{3}$ & $\mathrm{Fe}_{2} \mathrm{O}_{3}$ & $\mathrm{CaO}$ & $\mathrm{MgO}$ & $\mathrm{K}_{2} \mathrm{O}$ & $\mathrm{Na}_{2} \mathrm{O}$ & $\mathrm{TiO}_{2}$ & $\mathrm{LOI}^{* *}$ \\
\hline Syenitic rock & 65.51 & 15.1 & 5.98 & 0.7233 & trace & 5.093 & 5.773 & 0.31 & 1.07 \\
\hline SLSG* & 73.73 & 1.202 & 0.068 & 10.73 & 0.02 & 0.014 & 13.76 & 0.029 & - \\
\hline
\end{tabular}

For crystalline phases identification, $\mathrm{x}$-ray diffraction analysis were performed with Burkur AXS X-ray Diffractometer using the monochromatic $\mathrm{Cu} \mathrm{K \alpha l}$ line $(\lambda=1.54056 \AA)$. The microstructure with microanalysis was determined by scanning electron microscope (SEM/EDX SEM Model Quanta 250, Holland). Density is obtained for some selected samples using quantachrome (Upyc 1200e V5.03) by helium gas, and Archimeds method. Vickers microhardness value (model HV-1000 Micro Hardness Tester) was obtained using load $100 \mathrm{~g}$ and time with 15 second. 
Hamzawy, et al.

Table 3: Batch constituents with additives $\mathrm{H}_{3} \mathrm{BO}_{3}, \mathrm{MgF}_{2}$ and $\mathrm{CaF}_{2}$.

\begin{tabular}{|l|c|c|c|c|c|}
\hline \multirow{2}{*}{ Sample No. } & \multicolumn{5}{|c|}{ Molar ratio } \\
\cline { 2 - 6 } & Re Sy* & SLSG** & $\begin{array}{c}\text { Additives } \\
\text { Boric acid } \\
\mathrm{H}_{3} \mathrm{BO}_{3}\end{array}$ & $\mathrm{MgF}_{2}$ & $\mathrm{CaF}_{2}$ \\
\hline B-free & 50 & 50 & - & - & - \\
\hline B-con & 50 & 50 & 5 & - & - \\
\hline 2-MgF2 & 50 & 50 & 5 & 3 & - \\
\hline 3-MgF2 & 50 & 50 & 5 & 5 & - \\
\hline 4-CaF2 & 50 & 50 & 5 & - & 3 \\
\hline 5-CaF2 & 50 & 50 & 5 & - & 5 \\
\hline *Ne Sy: Nepheline Syenitic rock **SLSG: Soda-Lime-Silica-Glass \\
\hline
\end{tabular}

\section{Result and discussion}

\section{$X$-ray diffraction analysis}

The developed crystalline phases after heat treatment at $800,850,900$ and $950^{\circ} \mathrm{C}$ for $2 \mathrm{~h}$ have been identified for some selected samples (B-free, B-containing, 2- $\mathrm{MgF}_{2}, 3-\mathrm{MgF}_{2}, 4-\mathrm{CaF}_{2}$ and 5- $\mathrm{CaF}_{2}$ ). Crystallization of nepheline $\left((\mathrm{K}, \mathrm{Na}) \mathrm{AlSiO}_{4}\right)$ with a hump were detected in B-free and B-containing specimens at $800^{\circ} \mathrm{C}$ (Fig. 7 and 8). The nepheline indexed peaks were at 2.988, 3.834, 3.271, 2.324, 2.885, $3.00,2.57,3.266 \AA$ (JCPDS file no. 88-1231). In 2- $\mathrm{MgF}_{2}$ and $3-\mathrm{MgF}_{2}$ specimens, heat-treated within 800 and $950{ }^{\circ} \mathrm{C}$, augite $\left.\left(\mathbf{C a}_{0.61} \mathbf{N a}_{0.25} \mathbf{F e}_{0.07} \mathbf{M g}_{0.07}\right)\left(\mathbf{M g}_{0.65} \mathbf{F e}_{0.1}\right) \mathbf{A l}_{0.22} \mathbf{S i}_{2} \mathbf{O}_{6}\right)$ were identified with an amorphous hump (Fig. 8). On the other hand, in $4-\mathrm{CaF}_{2}$ and $5-\mathrm{CaF}_{2}$ specimens, heat treated within the previous temperature, xonotlite $\left.(\mathbf{C a}, \mathbf{N a})_{6} \mathbf{S i}_{6} \mathbf{O}_{17}(\mathbf{F})_{2}\right)$ was developed with a low amorphous hump (Fig. 8). In general, the intensity of $\mathrm{x}$-ray lines increases with increasing of the heat-treatments parameter from 800 to $950^{\circ} \mathrm{C}$ (compare Fig. 8). Due to the high ratio of $\mathrm{SiO}_{2}$ and $\mathrm{Al}_{2} \mathrm{O}_{3}$ which cause relatively high viscosity and sluggish mobility of cations at lower temperature that lead to the persistence of amorphous without change and an amorphous hump were detected. However, in literature alumina and silica in the glass batches are effective in rising the viscosity of the glass due to formation of $\mathrm{SiO}_{4}$ and $\mathrm{AlO}_{4}$ polymorphs which effect on the network strength of the glass structure (MacDowell, 1990). Both $\mathrm{MgF}_{2}$ and $\mathrm{CaF}_{2}$ have a different effect on the sintering process and the crystallization behavior. $\mathrm{MgF}_{2}$ facilities the crystallization of augite while $\mathrm{CaF}_{2}$ additive affected on the crystallization of fluor-amphibole (xonotlite).

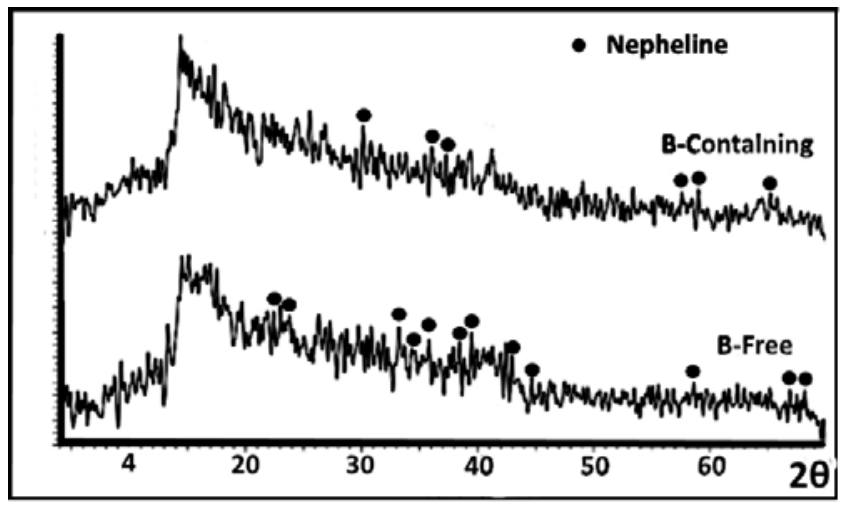

Fig. 7: XRD patterns of B-free and $\mathrm{B}$-containing glasses heat treated at $800^{\circ} \mathrm{C} / 2 \mathrm{~h}$.

Looking to the developed crystalline phases, although nepheline has been reported to be composed mainly $\mathrm{NaAlSiO}_{4}$, it can accept considerable amount of Ca, K and Fe (Kimura, and Ikeda, 1995). Also, augite can accept many cations in its structure such as $\mathrm{Na}^{+}$and, $\mathrm{Fe}^{+2}, \mathrm{Fe}^{+3}, \mathrm{Mn}$, Ti and $\mathrm{Al}^{+3}$ (Klein, and Hurlbut, 1993), Crystallization of xonotlite was enhanced in $\mathrm{CaF}_{2}$-containing samples. Crystallization of xonotlite was enhanced in $\mathrm{CaF}_{2}$ - containing samples. Xonotlite can accept respectable amount of $\mathrm{Fe}, \mathrm{Na}$ (Eberhard, et al, 1981), which is enriched in calcium and fluorine (Hamedani, et al, 2013). In general, 


\section{Characterization of Abu Khruq nepheline syenite}

boron lowers the melting temperature or the viscosity of glass. Fluorine not only affect in lowering viscosity but also enhancing the formation of F- containing droplet of phase separation which consider as nuclei for the subsequent crystallization process

Fig. 8: XRD patterns of 2$\mathrm{MgF}_{2}, 3-\mathrm{MgF}_{2}, 4-\mathrm{CaF}_{2}$ and $5-\mathrm{CaF}_{2}$ glasses heat treated at $800^{\circ} \mathrm{C}, 850^{\circ} \mathrm{C}, 900^{\circ} \mathrm{C}$ and $950^{\circ} \mathrm{C} / 2 \mathrm{~h}$.
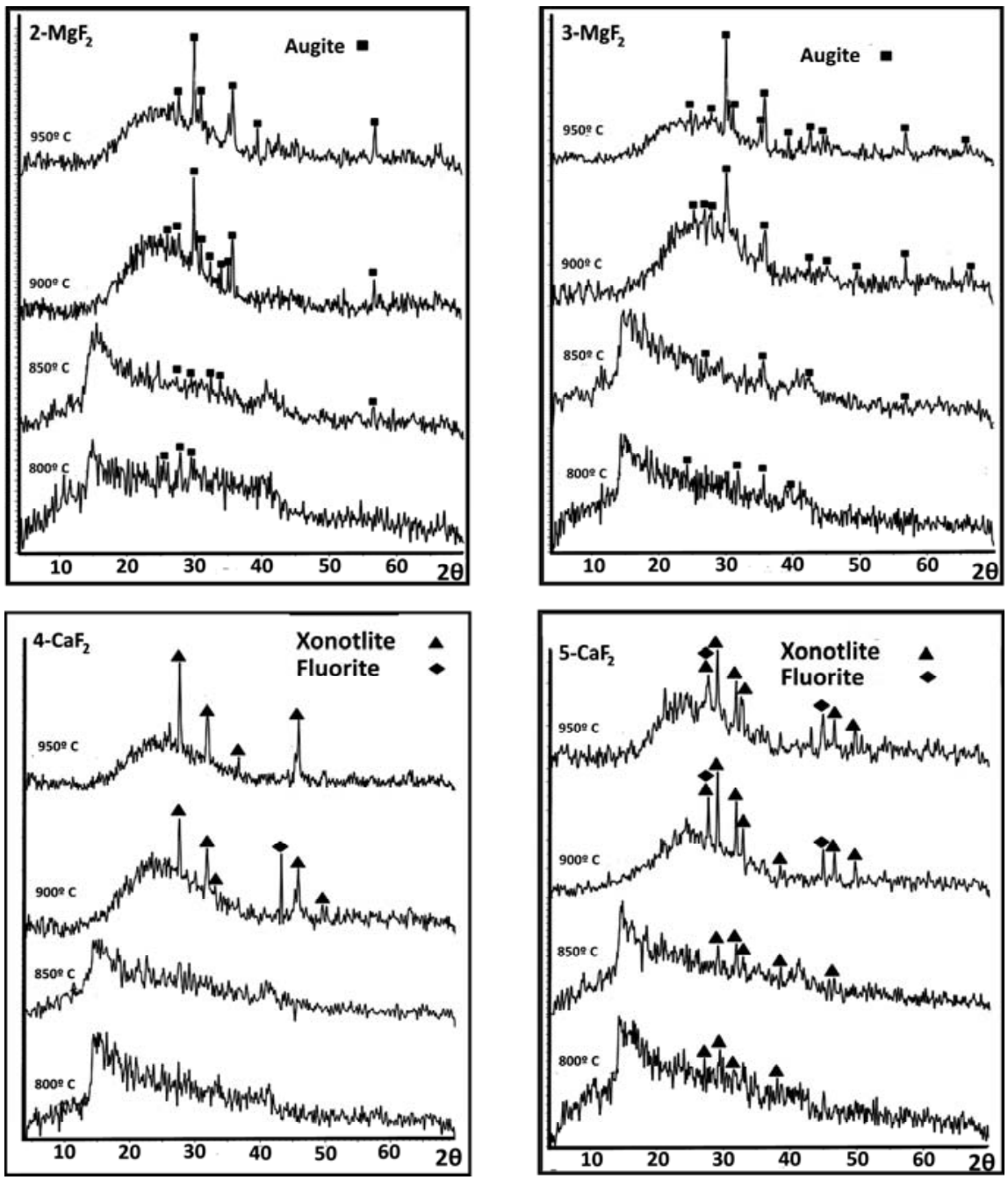

\section{SEM results}

SEM photomicrographs of the sintered glass-ceramic samples heat-treated at $800^{\circ} \mathrm{C}$ and $850^{\circ} \mathrm{C}$ for $2 \mathrm{~h}$ are represented in figure 11a and $\mathrm{b}$. Microstructure of the B-free glass ceramic shows prismatic shape crystals immerged in glass matrix, while in B-containing sample, an impression of prismatic shape that tend to be rod-like shape with distinct residual glass with average crystalline size in thickness $(938.3 \mathrm{x}$ $246.5 \mathrm{~nm}$ ). The observation in $2-\mathrm{MgF}_{2}$ at $800^{\circ} \mathrm{C}$ and $3-\mathrm{MgF}_{2}$ at $800^{\circ} \mathrm{C}$ and $850^{\circ} \mathrm{C}$ photographs show prismatic crystals spread in glassy matrix where they increased in size by rising of heat-treatment. The thicknesses of the later prismatic crystals were within $2.869 \times 0.255 \mu$, and $1.432 \times 1.561 \mu$, respectively. Also, prismatic-like or needle-like crystals were developed in the $4-\mathrm{CaF}_{2}$ at $800^{\circ} \mathrm{C}$ and $5-\mathrm{CaF}_{2}$ at $800^{\circ} \mathrm{C}$ and $850^{\circ} \mathrm{C}$ specimens. Fig. 10 ( $\mathrm{a}$ and $\mathrm{b}$ ), the later increased prismatic crystals were in size by heat treatment. The thickness of later prismatic crystals were within $0.823 \times 0.21 \mu$, and $0.9 \times 0.17 \mu$, respectively.

\section{Physical properties}

\section{Density and microhardness}

The densities of some selected sintered glass ceramic samples are reported in Table 4. It is evident that as the amount of fluorine content increase the density decrease between $\left(2.14-2.3 \mathrm{~g} / \mathrm{cm}^{3}\right)$ while B- 


\section{Hamzawy, et al.}

containing and B-free glass heat treated at $750^{\circ} \mathrm{C}$ show higher in density $\left(2.48\right.$ and $\left.2.52 \mathrm{~g} / \mathrm{cm}^{3}\right)$, respectively. The decrease in density may be because of the difference between density of crystalline and residual glass phase cause to lack the porosity. Consequently, density increase due to lowering in atomic mobility at $750^{\circ} \mathrm{C}$ and by increasing of fluorine content lead to increase mobility, sintered process and decrease viscosity of glass (Jang and Matsubara, 2005).
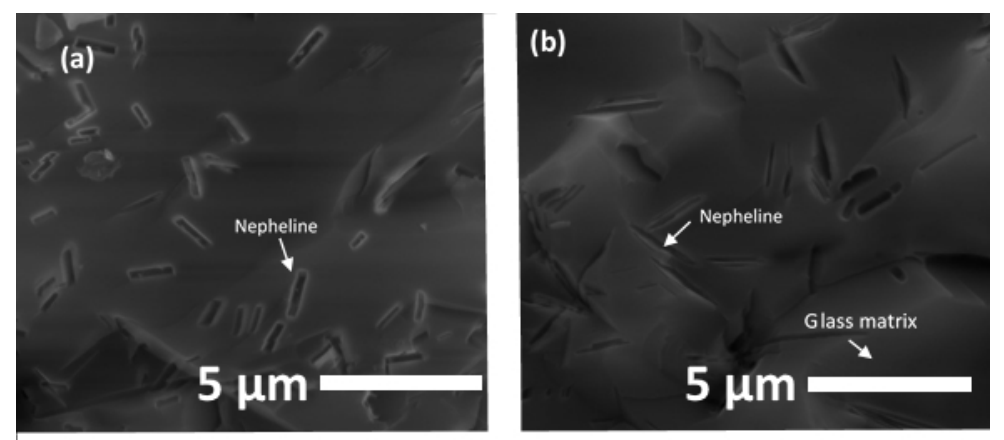

Fig. 9: SEM micrographs of (a) B-free, (b) B-content, (c) $2-\mathrm{MgF}_{2}$, (d) $3-\mathrm{MgF}_{2}$, (e) 4$\mathrm{CaF}_{2}$ and (f) $5-\mathrm{CaF}_{2}$ glasses heat treated at $800^{\circ} \mathrm{C} / 2 \mathrm{~h}$.
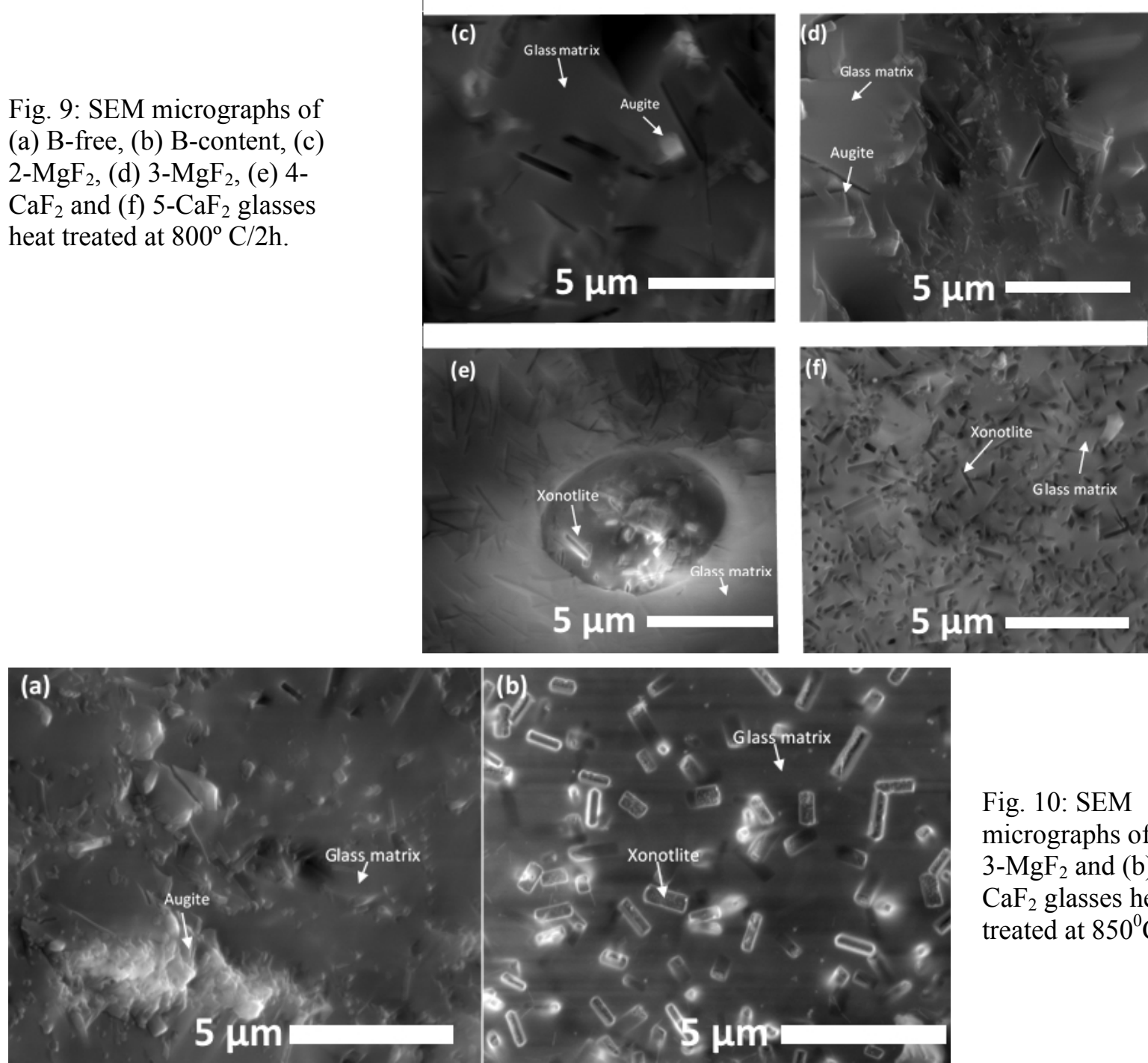

Fig. 10: SEM

micrographs of (a) $3-\mathrm{MgF}_{2}$ and (b) 5$\mathrm{CaF}_{2}$ glasses heat treated at $850^{\circ} \mathrm{C} / 2 \mathrm{~h}$. 


\section{Characterization of Abu Khruq nepheline syenite}

The result of the present crystalline phases was (5.5-6 Moh's scale) $650-750 \mathrm{~kg} / \mathrm{mm}^{2}$ for augite (Khater, et al. 2015), (5.5-6 Moh's scale) $650-750 \mathrm{Kg} / \mathrm{mm}^{2}$ for nepheline (Wang, el al. 1993) and $5.5 \mathrm{Moh}$ 's scale for xonotlite. In the present work, the sintered $\mathrm{B}$-free and $\mathrm{B}$-containing glass samples at $750^{\circ} \mathrm{C} / 2 \mathrm{~h}$ were higher than that in $2-\mathrm{MgF}_{2}$ and $4-\mathrm{CaF}_{2}$ samples at $800^{\circ} \mathrm{C} / 2 \mathrm{~h}$ and $3-\mathrm{MgF}_{2}$ and $5-\mathrm{CaF}_{2}$ samples at $900^{\circ} \mathrm{C} / 2 \mathrm{~h}$. Microhardness values decrease by temperature of sintering accompany with crystal growth in the samples. However, many factors effect in the microhardness value such as crystal phase, residual glassy phase, porosity and their ratios in the sample. The decrease of the porosity due to the crystallization or the remelting lead to increase the microhardness and vice versa and in our work the hardness of the surface decrease with increase in porosity in specimens (Marghussian, and Dayi Niaki, 1995; and Jang, and Matsubara, 2005).

Table 4: Microhardness and density for some selected glass ceramics.

\begin{tabular}{|c|c|c|c|}
\hline Sample code & Heat treatment & $\mathrm{Hv}\left(\mathrm{Kg} / \mathrm{mm}^{2}\right)$ & Density $\mathrm{g} / \mathrm{cm}^{3}$ \\
\hline B-free & \multirow{2}{*}{$750^{\circ} \mathrm{C} / 2 \mathrm{~h}$} & 676.2 & 2.5213 \\
\hline B-containing & & 655.2 & 2.4815 \\
\hline $2-\mathrm{MgF}_{2}$ & \multirow{2}{*}{$800^{\circ} \mathrm{C} / 2 \mathrm{~h}$} & 466.5 & 2.1464 \\
\hline 4-CaF 2 & & 397.5 & 2.2333 \\
\hline $3-\mathrm{MgF}_{2}$ & \multirow{2}{*}{$900^{\circ} \mathrm{C} / 2 \mathrm{~h}$} & 396.5 & 2.3082 \\
\hline $5-\mathrm{CaF}_{2}$ & & 436.75 & 2.2192 \\
\hline
\end{tabular}

Fig. 11: adensity and b-Vickers hardness

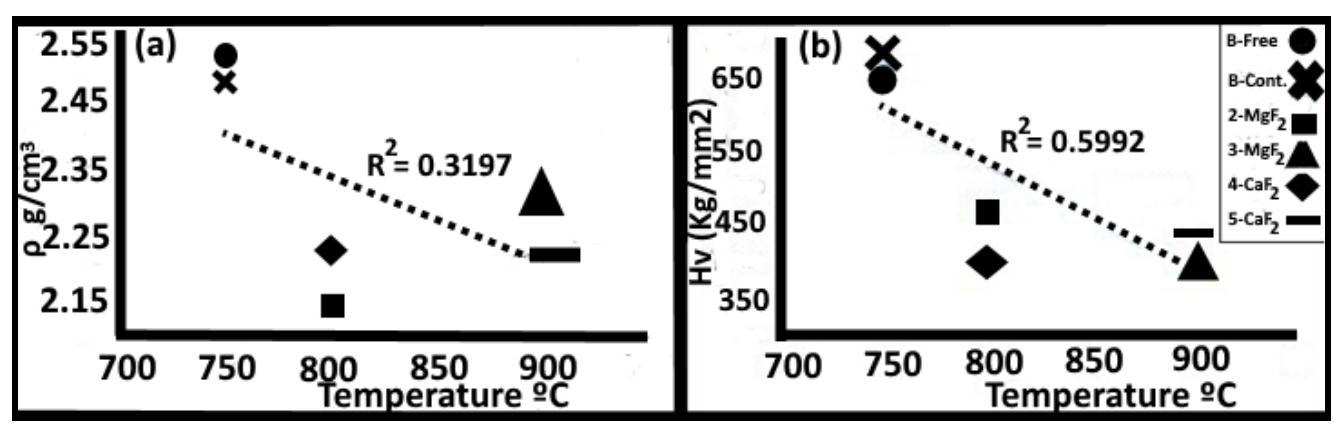

\section{CONCLUSIONS}

Abu Khruq ring complex is made up of nepheline syenite, syenite and quartz syenite. Petrographical and Chemical analysis were achieved to define the chemical and mineral composition and to know the nature of the various rock types. The different types of alkaline syenitic rocks from outer and inner ring represent as a slightly down of $\mathrm{Na}_{2} \mathrm{O}$ and enrichment of $\mathrm{SiO}_{2}$ occurred toward outer ring. Also, the syenitic rocks have a consider value of $\mathrm{Al}_{2} \mathrm{O}_{3}\left(12.8-17.3\right.$ wt. \%) and $\left(\mathrm{Na}_{2} \mathrm{O}+\mathrm{K}_{2} \mathrm{O}\right)$ are above 8.5 wt. \% which might mean developed magma from deep crustal source of mixed material from the mantle. According to plate tectonic theory, the different types of syenitic rocks placed in within plate anorogenic.

Sintered glass-ceramics were obtained from processed nepheline syenite-soda lime silicate glasses. Nepheline, augite, xonotlite and fluorite were crystallized phases through sintering process of these glasses. Fine grained microstructure was obtained in micro- and nano-sized in all sintered glass-ceramic samples, however, increase of sintering temperature lead to increase in crystal growth size and intensity of x-ray diffraction patterns. Vickers hardness was high in augite containing samples rises with blank sample at low temperature and decrease by increase amount of $\mathrm{F}^{-}$and heat treatment.

\section{REFERENCES}

Aitken, B. and Beall, G. (1994): Glass ceramics, Material Science and Technology series, Ed. Chan et al. II, chapter 5, 269-294.

An-Min, H., Kai-Ming, L., Fei, P.,Guo-Liang,W. and Hua, S. (2004): Crystallization and microstructure changes in fluorine-containing $\mathrm{Li}_{2} \mathrm{O}-\mathrm{Al}_{2} \mathrm{O}_{3}-\mathrm{SiO}_{2}$ glasses, Thermochimica Acta. 413, 53-55. 


\section{Hamzawy, et al.}

Batchelor, R. A. and Bowden, P. (1985): Petrogenetic interpretation of granitoid rock series using multicationic parameters. Chem. Geol., 48:43-55.

Beall, G. H. (1989): Design of glass-ceramics. Review of solid state Science, vol. 3(3-4), 333-354.

Bonin, B. (1974): Hypersolvus subvolcanic complexes and the younthful Atlantic basin. Geol. Medit., 1, 139-142.

De La Roche, H., Leterrier, J., Grandclaude, P., and Marchal, M. (1980): A classification of volcanic and plutonic rocks using R1-R2 diagram and major-element analyses: its relationship with current nomenclature. Chem.1 Geol. 29, 183-210.

Deng, W., Cheng, J., Tian, P. and Wang, M. (2012): Chemical durability and weathering resistance of canasite based glass and glass-ceramics. J. Non-crystalline solids. 358, 2847-54.

E1 Ramly, M. F. and Hussein, A. A. A. (1982): The alkaline ring complexes of Egypt. Geol. Surv. Egypt Pap. 63, 16.

E1 Ramly, M. F. and Hussein, A. A. A. (1985): The alkaline ring complexes of Egypt. J. Afr. Earth Sci. 3, 77-82.

Eberhard, E., Hamid, S.A. and RÄottger, B. (1981): Strukturverfeinerung und Polytypie von Xonotlit $\mathrm{Ca}_{6}$ $\left[\mathrm{Si}_{6} \mathrm{O}_{17}\right](\mathrm{OH})_{2}$ : Zeits. Krist., 154, $271-272$ (in German).

El Afandy, A. H. and Abdalla, H. M. (2001): Geochemistry of radioactive mineralization of Abu Kruq ring complex, South Eastern Desert, Egypt. Egypt Mineral 13, 1-34.

El Afandy, A. H., El Nahas, H. A., Dawood, N. A. and Asran, H. M. (2012): Geochemistry, mineralogy, and radioactivity of Upper Cretaceous Abu Khruq Ring Complex, South Eastern Desert, Egypt. Arab. J. Geosci. 6, 2855-71.

EL Ramly, M. F., Budanov, V. I., Dereniuk, N. E., Armanious, L. K. and Hayek, G. G. (1969): A petrological study on the central part of Gabal Abu Khruq ring complex. Geol. Surv. Egypt. Paper 51.

Hamedani, M. T., Marghussian, V. K. and Sarpoolaky, H. (2013): Effect of composition and heat treatment on the phase evaluation and mechanical properties of tough miserite-based glass ceramics. J. of NonCryst. Solids 382, 112-120.

Hamzawy, E. M. A. and Khater G. A. (2005): Crystallization of processednepheline syenite-magnesite glasses. Adv. Appl. Ceram., 104(6), 277-281.

Hashad, A. H. and El Reedy, M. W. (1979): Geochronology of the anorogenic alkali rocks, south Eastern Desert, Egypt. Ann. Geol. Surv. Egypt. 9, 81-101.

Irvine, I. N. and Baragar, W. R. A., (1971): A guide to the chemical classification of common volcanic rocks, Can. J. Earth Sci. 81, 523-548.

Jang, B. and Matsubara, H. (2005): Influence of porosity on hardness and Young's modulus of nanoporous ED-PVD TBCs by nanoindentation. Materials letters 59, 3462-3466.

Khater, G., Mamduh, O. and Hamzawy E. M.A., (2015): Augite-anorthite glass-ceramics from residues of basalt quarry and ceramic wastes. Processing and Application of Ceramics. 9 (2), 117-123.

Kimura, M. and Ikeda, Y., (1995): Anhydrous alteration of Allende chondrules in the Solar Nebula II, alkali-Ca exchange reactions and formation of nepheline, sodalite and Ca-rich phases in chondrules. Proc. NIPR Symp. Antract. Meteorites. 8, 123-138.

Klein, C. and Hurlbut, C. S. (1993): Manual of mineralogy: (after James D. Dana), Jr. - 21st ed., Wiley international ed. 474-487.

Lameyre, J. (1974): Les Marques de 1, eau dan les leucogranites du massif Central Francais. Bull Soc Fra $15,288-295$.

Le Maitre R. W., (1989): Classification of igneous rocks and glossary of terms. Blackwell, London. 193.

Lutz, T. M., Foland, K. A., Faul, H. and Srogi, L. (1988): The strontium and oxygen isotopic record of hydrothermal alteration of syenites from the Abu Khruq complex, Egypt. Contrib. Mineral. Petrol. 98, 212-23.

MacDonald, G. A. (1968): Composition and origin of Hawaiian lavas. Geol. Soc. Am. Mem., I16, 417-52.

MacDowell, J. F., (1990): Aluminoborate glass-ceramics with low thermal expansivity. J. Americ. Ceram. Soc. 73 (8), 2287-2292. 


\section{Characterization of Abu Khruq nepheline syenite}

Maniar, P. D. and Piccoli, P. M., (1989): Tectonic discrimination of granitoids Bull Geol Soc Am. 101, 635-643.

Marghussian, V. K. and Dayi Niaki, M. H. (1995): Effects of composition Changes on the Crystallization behavior and properties of $\mathrm{SiO}_{2}-\mathrm{Al}_{2} \mathrm{O}_{3}-\mathrm{CaO}-\mathrm{MgO}\left(\mathrm{Fe}_{2} \mathrm{O}_{3}-\mathrm{Na}_{2} \mathrm{O}-\mathrm{K}_{2} \mathrm{O}\right)$ glass-ceramics. J. of the European Ceramic Soc. 15, 343-348.

McMillan, P. W., (1979): Glass Ceramics. Second ed. Academic Press, London.

Meneisy, M. Y. and Kreuzer, H., (1974): Potassim-argon ages of nepheline syenite ring complexes in Egypt. Geol. Jb. D-9, 33-39.

Mogahed, M. M. (2016): Petrogenesis of cogenetic silica-oversaturation and undersaturated syenites of Abu Khruq ring complex, South Eastern Desert, Egypt. J. of African Earth Sciences. 124, 44-62.

Mukherjee, P. D. and Das, S. K. (2013): $\mathrm{SiO}_{2}-\mathrm{Al}_{2} \mathrm{O}_{3}-\mathrm{CaO}$ glass ceramics: Effects of $\mathrm{CaF}_{2}$ on crystallization, microstructure and properties. Ceramics International 39, 571-578.

Pearce J. A., Harris N. B. A. and Tindle A. G. (1984): Trace elements discrimination diagrams for tectonic interpretation of granitic rocks. J. Petrol., 25: 956-983.

Salama, S. N., Salama, S. M. and Darwish, H. (2002): The effect of nucleation catalysts on crystallization characteristics of aluminosilicate glasses, Ceram-Silicaty 46, 15-23.

Serecsists, C. McC., Faul, H., Roland, K.A., EL Ramly, M.F. and Hussein, A.A. (1979): Alkaline ring complexes in Egypt: their ages and relationship to tectonic development of the Red Sea. Ann. Geol. Surv. Egypt. V.9, 102-116.

Shand, S. J. (1951): Eruptive Rocks, John Wiley, New York.

Thompson, R. N., Morrsion, M. A. Hendry, G. L. and Parry, S. L. (1984): An assessment of the relative roles of crust and mantle in magma genesis: an elemental approach. Philos. Trans. R. Soc. London, A. 310, 549-590.

Wang, M., Wu, N. and Hon, M. (1993): Preparation of nepheline glass-ceramics and their application as dental porcelain. Materials chemistry and Physics. 37, 370-375

Wright, J. B., (1969): A simple alkalinity ratio and its applications of nonorogenic granites genesis. Geol. Mag., 106, 370-384. 
Hamzawy, et al.

توصيف نيفلين سيانيت ابو خروج لتعويض زجاج الجير الصودي لتحضير السيراميك الزجاجي

عصمت حمزاوي وعبد المنعم سلطان و باهر القليوبي و احمد يحي

الخلاصة

تقع منطقة جبل ابو خروج بجنوب الصحراء الثرقية و تتكون من النفلين سبانيت ، السبانيت و الكوارتز سيانيت ـ امكن من الدراسة البتروجرافية و التحليل الكيميائى معرفة التركيب المعدنى لمعرفة الطبيعة المختلفة للصخور الموجوده بالمنطقة .

من خلال الدراسة الجيوكيميائية تميزت الصخور السيانيتية الجوفية بزياده نسبة أكسبد الصوديوم و نقصان نسبة أكسيد السيليكون

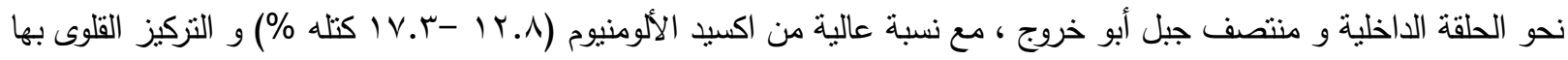

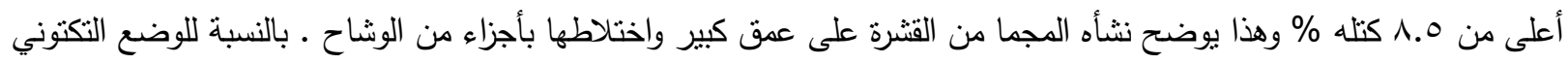

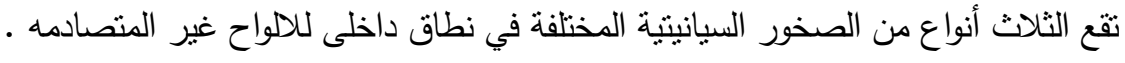
تم تحضير الزجاج السيراميكى الملدن من المواد الأولية محلية طبيعية و هي النفليلن سيانيت و الكوارتز سيانيت مع اضافة حض البوريك لخلطات الزجاج لتقليل درجة حرارة الانصهار و لزوجة صهير الزجاج • تم اضافة فلوريد الماغنسيوم و فلوريد

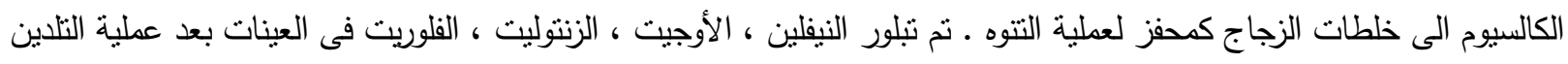
ـ أظهرت النتائج ان الزجاج (B-free and B-containing) ينبلور فيه معدن النفيلين في وسط زجاجى سليكيتى، بينما الزجاج اذي يحتوى على فلوريد الماغنسيوم يحفز تكوين معدن الاوجيت في وسط زجاجى سيليكتى ، و الزجاج الذى بحتوى على فلوريد

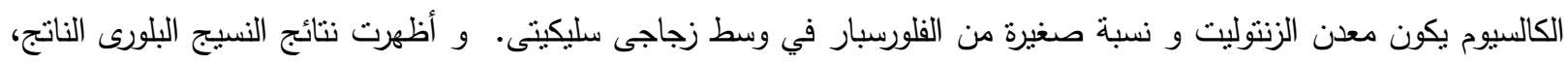

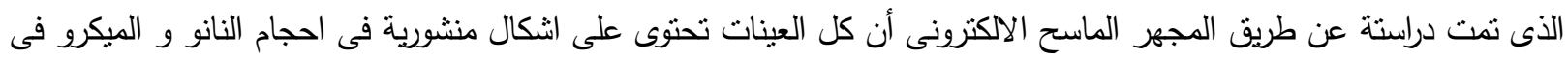

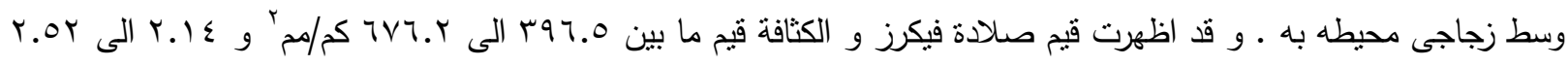

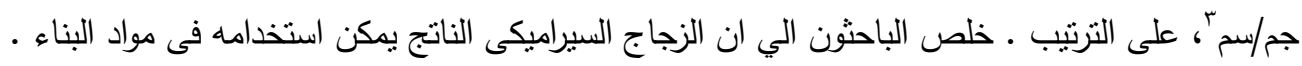

